\title{
Gender and TVET in Africa
}

\section{A Review of the Literature on Gender Issues in Africa's TVET Sector}

\author{
ELINOR BRAY-COLLINS, NALINI ANDRADE \& CATHERINE WANJIRU
}

\begin{abstract}
In this paper we present the findings of an extensive review of the literature on gender issues in Africa's TVET sector. Specifically, we highlight a number of themes which emerge from this review and propose a theoretical framework for understanding TVET institutions as gendered spaces. The TVET sector is frequently spoken about the potential it holds for the advancement of the SDGs on the African continent as well as the achievement of Agenda 2063 - indeed, it is seen as crucial to achieving these goals. What the literature suggests however, is that in the absence of gender-responsive reforms rooted in an understanding of how "gender regimes" operate and persist, TVET institutions may tend to be sites of reproduction of patriarchal dynamics as opposed to sites of their transformation.
\end{abstract}

KEYWORDS: Gender; TVET; Africa; Education

\section{Introduction}

Technical, vocational education and training (TVET) has long been recognized as a key component of human resource development (HRD) and a vital tool for socio-economic development (UNESCO 2018). More recently, the TVET sector has been identified for the potential it holds for the advancement of the SDGs on the African continent as well as the achievement of Agenda 2063 - indeed, it is seen as crucial to achieving these goals (African Development Bank, 2021). ${ }^{1}$ TVET has been hailed as "the answer to the skills shortage and skills mismatch in

\footnotetext{
Agenda 2063: The Africa We Want is Africa's “blueprint and master plan for transforming Africa into the global powerhouse of the future. It is the continent's strategic framework that aims to deliver on its goal for inclusive and sustainable development and is a concrete manifestation of the pan-African drive for unity, self-determination, freedom, progress and collective prosperity pursued under Pan-Africanism and African Renaissance" (African Union, see: https://au.int/en/agenda2063/overview). Both agenda 2063 and the SDGs call for the equal participation of all persons in work and education. Specifically, goal 5 aims to achieve gender equality and the empowerment of all women and girls. Goal 4 focuses on quality education for all and specifies gender quality in TVET under its sub-goals. Goal 8 focuses on decent work and economic growth, and specifies the
} 
Africa" and "the missing link for the training and integration of youth in the labour market" (Ibid). TVET no doubt holds tremendous potential for increasing employment, economic development and ultimately economic empowerment for young Africans in particular. But how well do TVET institutions contribute to the types of social change, such as the transformation of oppressive gender dynamics, that are also needed if these goals are to be achieved? Through this review of literature on gender issues in Africa's TVET sector, we aim to shed light on this question. ${ }^{2}$ We identify several gender themes which emerge from this review and propose a theoretical framework for understanding TVET institutions as gendered spaces. Specifically, we highlight ways in which gender inequalities create barriers and dynamics within the TVET sector that, because of the direct relationship to the world of work, have clear and direct repercussions for women's access to and participation in the labour market, and for their economic empowerment and security long-term. What the literature suggests is that while TVET has the capacity to contribute to the advanced of development goals on the African continent, in the absence of gender-responsive reforms rooted in an understanding of how "gender regimes" operate and persist, TVET institutions may tend to be sites of reproduction of patriarchal dynamics as opposed to sites of their transformation.

There are three main findings of this review. The first is that Gender gets a great deal of lip service in grey literature but little systematic research and theorization. Moreover, there is not a strong connection between the studies on Gender and TVET and African Feminist scholarship or African post-colonial scholarship. The second finding in this review is that TVET institutions and their services are deeply gendered in nature, meaning, they reflect the broader socio-cultural dynamics of the societies in which they exist. These societal dynamics are patriarchal and constitute a web of socio-cultural, political and economic relationships that create systems of gender inequality. However, what the literature indicates is that TVET institutions do not simply reflect gender dynamics of broader society, they also work to perpetuate them. The third and overall finding of this review is therefore that in the absence of gender-responsive reforms designed to address the drivers of inequality within TVET institutions on the African continent, TVET may tend to perpetuate gender inequalities rather than acting as potential sites of their transformation. These arguments are laid out in turn below.

\section{Lacking Connection to African Feminist and Post-Colonial Scholarship:}

There is a striking paucity of studies and scholarship on the relationship between gender equality in TVET, and the connection to women's economic empowerment and equality. Like the literature on TVET in Africa more generally (McGrath et al, 2019), the scholarship on gender, equality and TVET on the Africa continent is disjointed and under theorised, especially in terms of how gender inequality in the TVET sector hampers the promotion of sustainable development. The literature on gender and TVET also lack connections to the wider scholarship on gender equality and development in Africa and to the historical contexts that surround it, or as McGrath et al (2019) argues, to an understanding of the "contestations and compromises in specific historical and geographical spaces" (McGrathe et al, 2019, p.479). As a result, despite the widespread acknowledgement of gender inequality in the TVET sector, a comprehensive and holistic discussion of the potential that TVET has to promote gender equality more

importance of providing equal opportunities for women. As an educational sector closely related to employment outcomes, TVET clearly has a critical role to play in promoting gender equality in Africa, the promotion of the SDGs and Agenda 2063.

2 Because of the paucity of academic scholarship in this area, grey literature has also been included.

152

Gender and TVET in Africa

Futures of Education, Culture \& Nature - Learning to Become 
broadly, and the potential contribution this could in turn make to the promotion of Agenda 2063 and the SDGs, remains a gap.

Most of the literature on gender and TVET tends to focus on the gender disparities in enrolment, especially of females in non-traditional sectors. Recent studies by the ILO (2019) show that in 24 countries across regions of the African continent, females lagged behind males in terms of enrolment in TVET. Females who are enrolled in vocational training tend to be enrolled in courses that train them for lower-paying service or helping sectors such as secretarial work, beauty, childcare, etc. as opposed to traditional 'technical' trades such as electricity, construction, welding, plumbing, etc. (UNESCO 2012 \& 2013; Gaidzanwa, 2008). According to research by Save the Children (Romero and Folz, 2015), there is little focus on girls within TVET programming at post-primary level in Africa (Ibid.). In countries where informal employment is prominent, women are more likely to be overrepresented in informal labour. This limits their opportunities for accessing further education and training. For instance, women are less likely to take part in apprenticeships or have opportunities for work-integrated learning with master-craftspeople (ILO, 2014; ILO, 2018; ILO, 2020). Analysis of the informal sector in West Africa, for example, showed that women tend to acquire skills through unstructured, informal learning while they work, whereas men are more likely to have apprenticeships with experienced mentors (Nordman and Pasquier- Doumer, 2012). Unsurprisingly these educational disparities "trickle-up" and translate into gender inequalities in the labour market and in future economic status.

Several studies focus on a specific obstacle to gender equality in TVET, and/or the experiences of female students in specific programs and contexts within TVET institutions in specific countries. Most studies also conclude with brief recommendations for new policies and practices within TVET institutions, though few set these recommendations within the larger context of the relationship of TVET to labour, gender equality and sustainable development in Africa more broadly.

Gender issues receive varying degrees of attention in country-specific literature on TVET. As noted in UNESCO's (2013) review of TVET on the Southern African Development Community Region, the level of attention to equity has typically depended on the visibility of equityrelated issues, like gender equality, in other government policies which intersect with TVET policy (UNESCO 2013, p89). While the literature generally indicates the sector is in urgent need of gender-responsive reforms, both at the levels of policy, implementation and practice, it is important to highlight some of the efforts and gains in gender equality that have been made. The past decade has seen an increase in female participation in TVET across the continent (IDRC, 2019; UNESCO, 2011). Several African countries (for example, Mauritius, Kenya, Malawi, Tanzania, Rwanda, Seychelles, Uganda and South Africa) have targeted policy attention on increasing women's participation in TVET and specifically in male-dominated courses (Prendergast, 2020; Rubagiza, 2010; Leyaro, V. and Joseph, C. 2019; UNESCO 2020, Omukhulu, D. et al 2016, Bunyi, G 2003; NHRDC, 2007). However, despite the increases in female participation in TVET, and policy statements that signal the intention to promote equality, there remains a lack of both comprehensive research on gender equality as well as concrete implementation and oversight of gender-responsive measures as it relates to actual TVET practices. Indeed, men still dominate Africa's TVET sector (IDRC, 2019). 


\section{Gendered Dynamics within and external to TVET Institutions}

The obstacles to gender equality that are highlighted in the literature speak to the range of the broader nature of gender dynamics that exist across the African continent. These gender dynamics constitute a web of socio-cultural, socio-political and socio-economic relationships that create systems of gender inequality and which are inextricably connected to other complex challenges facing African countries (such as issues of sustainability and climate change, for instance) and which, it is important to note, negatively affect all of Africa's citizens, albeit unevenly. While a comprehensive theorization of the interconnections between gender dynamics, equality, TVET and the promotion of sustainable development are beyond the scope of this paper, this examination of the literature allows us to make an observation about this relationship, which constitutes the second finding of this literature review. Namely, Africa's TVET sector both reflects the gender dynamics of broader society and works to reinforce and perpetuate them. To explain, the gender inequalities found within TVET institutions are shaped by the dynamics of gender inequality that exist in broader society - categorized here as external-drivers of gender inequality. These external-drivers inequality give rise to a host of obstacles to the full and equal participation of women and girls within TVET institutions - categorized here as internal-drivers of gender inequality. ${ }^{3}$ Based on this review of literature, it can be postulated that in the absence of gender-responsive reforms within the TVET sector, African's TVET institutions will not only continue to reflect societal gender equalities, they will also work to reinforce and perpetuate them, either through their inaccessibility to a great number of women and girls, by funnelling them into low-paying sectors, by reinforcing gender stereotypes about women's capabilities and/or by not accounting for the safety and wellbeing of female students in their pursuit of training and education. Indeed, research on this area reveals that without comprehensive gender analysis and gender-responsive services, content, policies, strategies, and systems, TVET will, at best, fail to capitalize on the talents and skills present amidst Africa's female population, and at worst, serve to perpetuate gender inequalities at a broader societal scale (Adelakun, Oviawe, Garba, 2015).

Of course, gender inequality, and the oppression of women and girls, is not only an issue of human rights, it also works to the detriment of sustainable economic development for all. Promoting gender responsive TVET education makes "good economic sense" (Woldemichael, 2020). The links between women's economic empowerment and economic development and the positive correlation between girls' education and sustainable development is well documented. Equal access to education and employment for females not only benefits women, but also the families and communities they nurture (Ngugi, M. and Muthima, P., 2017; Tchouassi, 2012; Van den Bergh Collier, E., 2017; UNESCO, 2020; ILO, 2020). Girls in low-income countries who receive secondary education are $63 \%$ less likely to marry than girls without it and have fewer and healthier children. Children of literate mothers are over $50 \%$ more likely to live past the age of five and receive good nutrition. There is also a strong link between education and health benefits for women and girls and substantial evidence that an increase in a mother's education reduces the likelihood of dying in childbirth (UNESCO, 2019). Studies have also shown that the full and equitable participation of women in the labour market can create substantial economic gains in the border economy (Woldemichael, A., 2020). Estimates by Woldemichael (2020) show that increased equitable participation of women in the workforce could result in African countries increasing their GDP from 1\% (Senegal) to nearly 50\%

3 The distinction between external" and "internal" drivers of gender inequality is a false one as these dynamics are inextricably interconnected. However, for the sake of analysis, we make this distinction here in order to highlight the reinforcing dynamics between the two. 
(Niger) (Woldemichael, 2020). There is similar evidence when it comes to the relationship of gender equality to environmental sustainability, as research illustrates a positive correlation between the reduction of gender inequalities and decreased environmental degradation in several case studies across the continent (Agarwal, 2018; Ayalew Ali, D., Deininger, K. and Goldstein, M., 2014; World Bank Group, 2023). Africa needs a vital and gender responsive TVET sector in order to realize Agenda 2063, and Agenda 2030 (Asukwo, A., \& Moses, D., Ibanga, I., and Adamu Yusuf, M., 2019). The National Review of TVET Systems and Status in Africa and, more pointedly, any subsequent efforts to enhance Africa's TVET sector, represent an opportunity to highlight the connections between gender inequality, TVET, labour and sustainable development, and an opportunity to ensure that efforts to enhance Africa's TVET sector, capitalize on its potential as an engine for the creation of greater gender equality on the continent, and thereby promote just and sustainable development for all.

\section{Organization of this paper:}

This review is broken into three sections. The following section analyses the issues discussed in the literature on gender and TVET in Africa that we categorize here as external-drivers of gender-inequality, namely, how the socio-cultural and socio-economic systems shape gender roles to disadvantage women and girls. The next section analyses those issues raised in the literature which we categorize as internal-drivers of gender inequality. These are the aspects of TVET institutions themselves which create unequal gender outcomes in TVET education and the labour market. The third and final section reviews the policy landscape that frames gender in the African TVET sector.

\section{Externally Driven Challenges to Gender Equality in TVET}

Enhancing the empowerment of girls and women in Africa generally, and in TVET specifically, requires a holistic understanding of gender inequality as a broader system of societal norms that shapes beliefs, attitudes, and behaviour towards both males and females. These norms systematically disadvantage women and girls across realms of life (social, cultural, economic, political, civic, environmental, etc.) and put them at greater risk of hardship and suffering because of problems such as climate change, poverty, economic shocks, pandemics, etc. These externally driven gender dynamics give rise to systems of gender dynamics internal to the TVET sector which create gender inequalities within the sector. The overarching theme that emerges from this review of literature is that Africa's TVET sector is not immune to this system of gender inequality, rather, works to reflect it, and in many cases, to perpetuate it. Thus, when seeking to understand issues of gender inequality within TVET, it is important to first examine the context of externally driven issues of gender inequality in which the TVET sector operates. This type of systems analysis should inform the development of progressive legal frameworks and educational reforms that will promote and ensure gender equality and the economic empowerment of women and ensure their talents and skills are utilized across disciplines, industries, and sectors (Cheruiyot \& Munyi, 2019). This section discusses the key issues raised in the literature that occur outside of TVET institutions (namely, the "externallydriven" issues). 
Confining Gender Regimes: The Relegation of Women to the Domestic Sphere and Subsequent Barriers to their Participation and Success in TVET

Despite advances in gender equality, women and girls in Africa are still constrained by sociocultural norms, rooted in patriarchy, which profoundly shape their lives and curtail their equal access to education and employment. Beliefs and perceptions of women's role and purpose remain associated with the private, domestic realm and men with the public realm. These gender roles operate in the context of a web of social relations and informal institutions, or as Wallaby $(2004,2009)$ argues, "gender regimes", which have far-reaching implications across societal sectors, including education and employment.

Reflective of these gendered relations is the overwhelming agreement in the literature that the shared understanding that women and girls carry the responsibility of unpaid domestic responsibilities (which typically includes subsistence farming, cleaning, cooking, childbearing childcare, care for younger siblings, relatives, sick and elderly) and that this creates a formidable obstacle to their access, participation and success in education and training. In many African countries these duties are prioritized over a girls' education. Gaps in legal frameworks governing children's attendance further undermine girls' education as there are 25 African countries, with no minimum age for compulsory schooling. This results in girls from poor households being forced into domestic service or other forms of insecure employment from an early age (Gaidzanwa, 2008).

However, even when women can enter the labour market, domestic labour and childcare duties continue to create restrictions for their equal participation - something that is true across socio-economic categories as even in wealthier families, women still assume the majority of unpaid domestic labour, especially in relation to childcare. Women often lose their previous connection to their sector of employment because of childbearing and often lack the time, mobility, and complete flexibility necessary for full participation and/or advancement in education, training, and formal employment.

Of course, poverty exacerbates these problems. The poorer a family is, the less likely their girls are to complete education. Education is simply unaffordable for many families across Africa as school fees, or indirect costs (books, uniform, travel, etc.) can present insurmountable barriers for poor families (UNESCO, 2006; Ungeil, 2012). This affects girls' education the most as impoverished families may have the perceptions that educating girls is not a worthy "investment" in the future (like educating their boys would be). In other cases, a girls' education is sacrificed due to the need of families to reduce their own financial burden, while also generating financial gain through dowries collected in the marriage of daughters. The potential of African girls - their skills, intelligence and talent often go unrecognized or ignored as they are seen as either burdens or commodities for resource-poor families.

High rates of poverty and economic hardship are also linked to early marriage, another one of the leading obstacles cited in literature on contextual factors affecting girls' success in education generally, and TVET specifically (Lloyd and Mensch, 2008; Van den Bergh Collier, 2017; UNESCO, 2020; Arias, Evans, and Santos,2019; ILO, 2020). Approximately 37\% of girls in subSaharan Africa marry before age 18, and $11 \%$ are married before they turn 15 . However, with rates of early marriage as high as $76 \%$ (Niger), $67 \%$ (Chad) and 68\% CAR) and with 15 of the 20 countries with the highest rates of child marriage globally, early marriage is a significant problem on the African continent (UNICEF, 2020). These circumstances are frequently passed down to children born to young mothers, which place even further strain on a country's capacity to provide quality health and education services for such vulnerable groups in the population. 
Early marriage is linked to early pregnancy, which is another significant obstacle to girls' access to education and training that is discussed in the literature (Lloyd and Mensch, 2008; Van den Bergh Collier, 2017; UNESCO, 2020; Vila, 2015; Lifanda,2005), In many countries "schoolgirl pregnancy" means that girls are required by law to stop attending school, at least for a temporary period if not longer, when they become pregnant (Lloyd and Mensch, 2008). As Gaidzanwa (2008), points out even in countries where the law allows the return of student mothers to their studies (as is the case in Zimbabwe, South Africa, and Botswana, for example) the realities of motherhood and the cost of fees, coupled with inadequate facilities in the TVET environment, usually makes their return all but impossible, unless female students have an extremely strong support network. Moreover, girls and young women who become pregnant while enrolled in education often fear returning to school because of intimidation, mockery, and abuse (Gaidzanwa, 2008). Indeed, the literature highlights the issues of early marriage and pregnancy as two of the greatest contributors to drop out rates in primary, secondary, and tertiary education among girls in Sub-saharan African countries. Because of this Mbelle, Mabaso, Setswe \& Sifunda (2018), among others, argue that unplanned pregnancies among college/tertiary female students actually pose a serious public health concern in African countries in that it has negative knock-on effects in terms of educational progress, future career prospects and on economic development more widely (Mbelle, Mabaso, Setswe \& Sifunda, 2018; UNESCO, 2012; UNESCO, 2016).

These issues are compounded by others, such as rurality, another barrier to education highlighted in the literature that disproportionately affects the participation of women and girls in TVET. 70\% of Africa's poorest, the majority of them women, live in rural areas and cannot access urban labour markets or the vast majority of institutions offering vocational training and education. Like other educational institutions, TVET centres are often difficult to reach and insufficiently flexible to accommodate rural families (UNESCO, 2013; Lifanda, K.N. 2005; ILO 2020; Letta, T., Feleke, A. and Derseh, L., 2013). Poor transportation networks, lack of reliable systems of communications, all collude to trap women and girls in domestic and low-productivity agricultural sectors (Gaidzanwa, 2008).

Given the prominence of early marriage and early pregnancy in the literature on gender equality in TVET, it is important to understand these not just as social problems, but as TVET problems. Indeed, scholars argue that the high level of unplanned pregnancies among female college students in particular is indicative of the poor state of women's reproductive health services at TVET institutions (Mbelle, Mabaso, Setswe \& Sifunda, 2018; UNESCO, 2020; South African Government, 2020; Lifanda,2005) and argue for the provision of gender-responsive life skills training, sexual and reproductive health and rights information, and gender-aware student counselling services in TVET settings, for both male and female TVET students, would help mitigate the risks to women's' health, education and long-term economic well-being (ibid).

Early marriage and early pregnancy are linked to increased incidences of gender-based violence (GBV) and sexual harrassment, another serious barrier to the ability of girls and women to access to vocational education and training also leave them vulnerable to gender-based violence and sexual harassment. Gender-based violence is a pervasive challenge across Africa as it has negative repercussions for human, social, and economic development and creates serious impediments to women's well-being and the creation of healthy and peaceful communities (Beyene, Chojenta, Roba. et al. 2019). While a more complete discussion of GBV is beyond the scope of this review, it is crucial to highlight the urgency of GBV in relation to gender equality in TVET. GBV operates as both an external-driver and an internal-driver to gender equality in TVET institutions. Not only does it impede the ability of girls and women to 
access education, but TVET institutions themselves are often unsafe spaces for female students once they are there. Research has found that schools, colleges, and universities were often sites of violence for females (Krug, Mercy, Dahlberg and Zwi, 2002; Arnold, Gelaye, Goshu, Berhane and Williams, 2008). It is females attending TVET colleges, however, who have the highest lifetime prevalence of GBV out of all students - 30\% higher than university students, and yet the problem is not well addressed in TVET institutions (Beyene, et al. 2019; Mirsky, 2003). Gaidzanwa (2008) argues that gender violence by teachers, male pupils, support staff and even transport providers is implicated in the under-achievement, inferior performance and attrition of young women and girls from TVET institutions across sub-Saharan Africa. Young women and girls who have experienced gender-based violence are more likely to have poor rates of educational achievement and increased dropout rates compared to girls who do face violence (Kennedy, 2005; Kennedy and Bennett, 2006).

Gender inequality in Africa's TVET sector is hampered by the web of social relations and informal institutions, or "gender regimes", in broader society that confine men and women in socially constructed roles, and which work to the disadvantage and oppression of women and girls. Gender regimes create barriers to the education and training of females and thus also to their ability to gain secure, dignified, and well-paid employment. Of course, the aforementioned barriers affect the education of women and girls at every level - and the TVET sector is no exception. However, because of the direct relationship to the world of work, the implications for gender inequality in TVET have clear and direct repercussions for women's access to and participation in the labour market, and for their economic empowerment and security long-term. It is important to emphasize that because of their negative impact on women in TVET, these problems need to be understood as not just societal problems but also as TVET problems. It is to an analysis of the ways these external-drivers of gender inequality manifest in TVET institutions that we now turn.

\section{INTERNAL-DRIVERS OF GENDER INEQUALITY IN TVET INSTITUTIONS}

\section{Choosing the Path Most Taken: Gender Norms, Girls' Selection of Vocation, and Lower Pay for Working Women}

The literature points to a clear connection between external and internal drivers of gender inequality in TVET regarding the choice of profession of females and males. Gender relationships and dynamics strongly shape the choices women and girls make for themselves as well as the perceptions, preferences, and biases of their families and communities. As is the case in other regions around the world, socio-cultural norms and dynamics surrounding gender tend to result in women being over-represented in some sectors (especially those associated with the domestic sphere such as the care and service sector profession) and underrepresented in others (Buehren, N. and Van Salisbury, T. (2017), ILO 2020; Amoamah, M.O., Brew, E.M., Ampiaw,R.E. and Dadzie, J. (2016). Across Africa, this type of occupational segregation remains a predominant feature of both training and labour markets. Studies by the World Bank (2017), for example, show that the gender gap, and the under representation of women in particular, is particularly large in the more "technical" and industrial fields such as mechanics, electricity, construction, plumping, carpentry and welding. In Burkina Faso, for example, men outnumber women 5:1 in the industrial sectors (World Bank 2017b). In Uganda, three programs - construction, motor vehicle maintenance, and carpentry-account for two-thirds of male enrollment, whereas cooking or catering, beautician services, business-related studies, and tailoring account for two-thirds of female enrollment (Johanson and Okema, 2011 in 
Arias, O., Evans, D.K. and Santos, I. 2019). Even in cases where practices to increase opportunities for girls and women in non-traditional sectors exist, many girls and young women still choose not to (Amoamah, M.O., Brew, E.M., Ampiaw, R.E. and Dadzie, J. ,2016).

The literature highlights that this is especially true in the case of programs associated with science, technology, engineering, and math (STEM). When it comes to STEM, sexist and gendered stereotypes surrounding women's capability and suitability abound. STEM-related vocations tend to be seen by families, teachers, trainers, and by girls themselves, as a male domain - even more so than other non-traditional female sectors, like hospitality and food service (Agbara, W., Chagbe, M. B., \& Achi, T. T. (2018). Studies on female achievement in secondary schooling show that girls are far less likely to complete STEM subjects at the secondary level and few pursue STEM subjects through tertiary academic pathways at the postsecondary level. The same can be said for females in TVET institutions, as girls and young women rarely select STEM-related fields which are almost always more secure, higher paying jobs in the formal sector jobs. This results in the exclusion of girls and women from the STEM job market that is available in their region - a concern that will only grow more pronounced as Africa transitions to the fourth industrial revolution. Having said this, some studies have shown advances in gender equality and STEM subjects. Arias and Santos (2019) show countries such as South Africa, Lesotho, Namibia, and Zimbabwe, have achieved near gender parity among STEM graduates. Agricultural programs have also seen a steady increase of female participation, and female students now comprise more than 40 percent of agriculture graduates in Eswatini, Lesotho, Madagascar, Mozambique, Sierra Leone, South Africa, and Zimbabwe (Arias., Evans. and Santos, 2019 p264). Even in the fields where female participation remains at an overall low rate, there have been small gains in the last two decades. In Benin, Burundi, Eritrea, Ethiopia, Madagascar, Mozambique, and Namibia, for instance, there have been small but noticeable increases of approximately $5 \%$ in female participation in engineering programs since 2000 (UNESCO, 2015). Despite the progress, however, women in the region are still often constrained by family and household responsibilities as well as by negative attitudes toward women participating in higher education generally and in STEM fields in particular (Campos et al., 2015; World Bank, 2011).

Young women and men not only tend to choose different TVET fields, however, they are also differently remunerated for the work they do, with female-dominated occupations generating substantially less income on average than male-dominated occupations. For example, a recent study by the World Bank, showed that women who manage to gain employment in male-dominated sectors make up to three times more than women who stay in female-dominated sectors (Buehren and van Salisbury, 2017; Campos et al., 2015; World Bank, 2019). Discrepancies are also evident within occupations, as men tend to hold positions with more influence and responsibility and are paid more for the work they do. It is important to note, however, that these discrepancies are not typically associated with a higher level of skills or experience among men, which reveals sexism in hiring, promotion as well as a lack of pay equity between men and women (UNDESA, 2015). Moreover, women are more likely to work in the informal economy and therefore are less secure in their labour, more unregulated, and subject to a host of risks, including poor working conditions, sexual harassment, violence, etc.

The research confirms how difficult it is for girls and young women to escape unpaid domestic labour and agricultural feminization and engage in higher-paying, more secure, formal wage employment - something that only becomes increasingly difficult after marriage and/or motherhood. The literature leaves little doubt as to the need for new gender policies, practices in the TVET sector that support women's education and training in general and promotes their ability to pursue and maintain waged employment in the formal sector, and non- 
traditional sectors in particular (Dietrich, C., Huang, A, Thomas, A., Toujas-Bernaté, J., 2016). Indeed, studies show that additional and tailored support of female students can be particularly helpful when trying to address gender biases in their selection of fields of study and occupation. Inadequate counselling and career guidance for students means that males and females are not given an opportunity to reflect deeply on their choices of career and consider a different path. In Uganda, studies show that women who have received this type of counselling are much more likely to make the move into non-traditional sectors (Buehren and van Salisbury, 2017; Campos et al., 2015). Moreover, as discussed below, when girls and women have a champion, a mentor or role model in the TVET centre, they are much more likely to choose and remain in a non-traditional sector. The issue of vocational/professional selection is one where gender-responsive reforms, including offering women access to lifelong learning opportunities to close gaps in skills and knowledge, is poised to make a substantial difference in combating gender inequalities within labour sectors, if not society more broadly.

\section{Mechanisms of Gender Discrimination within TVET Institutions: The "Atmosphere of Masculinity"}

While the above factors shape the preference of young women and girls for certain subjects, for those who manage to overcome these barriers and enter TVET institutions, and especially for those who choose to train in non-traditional sectors, the literature describes a host of internal obstacles and barriers that await them within TVET institutions. For one, the

TVET training environment is rarely a gender-neutral space, and even more rarely a genderresponsive space, meaning one that anticipates gender barriers and promotes the full and equal participation of women. Rather, the training environment in TVET institutions tend to reflect and reinforce gender discrimination in both obvious ways - such as the lack of female role models, and subtle ways - such as the atmosphere of a classroom.

One of the more apparent ways a training environment can reproduce unequal gender outcomes is the lack of female instructors, staff and role models, though many studies cite the lack of gender-awareness of instructors to be more at the root of the problem (Van den Bergh, 2017; Rubagiza, 2010). Interestingly this is true for both traditional and non-traditional sectors. The lack of female presence within TVET can create an intimidating environment for young women and girls and discourage them from fully participating. While the lack of female staff (instructors or otherwise) is an issue, research indicates that the lack of gender-awareness among TVET instructors and staff may lie more at the root of the problem. Many studies discuss the lack of gender-awareness among teachers (whether male or female) as a possible factor in the unconscious reproduction of gender bias within the TVET learning environment (Bonzet and Frick 2019; Blumberg, 2008; Carlana, 2019; Gaidzanwa, 2007; UNESCO, 2016). In Zimbabwe, Gaidzanwa (2007) noted that post-secondary institutions, including TVET, can often feel unfriendly, if not "overtly gender-based, hostile environment for both female students and female staff members" (see: Modupe, Oladunni, 2014). Scholars further argue that many post-secondary institutions, including TVET colleges can present an unreceptive atmosphere for females because of the tendency for TVET to be seen as 'male territory,' and the prevalence of sexual innuendo, sexual harassment, as well as a gender lack of gender awareness of students as well as trainers (Gaidzanwa 2007; Mlama, 1998; Meena, 2007; Akinsanya,and Onah, 2012 ). In the UNESCO-UNEVOC conference on women and TVET, Helga Foster (2011) recounts female TVET participants who described an "atmosphere of masculinity that is strange and often offensive to women. There were mentions of violence, scathing language from fellow students and even trainers, the lack of separate toilet and leisure facilities, absent 
or costly transportation, inflexible timetables, and above all the lack of female teachers, trainers and management" (2011 p. 10).

Yet other studies find that male students are often given more attention than female students by instructors, even when the instructor is themselves a female. Gender bias is likely perpetuated in the pedagogical training that instructors receive, where these trainings exist. Combined, these environmental factors can make it difficult for female students to engage in learning in a way that allows them to reap the full benefits of their training. Rather, female TVET students, especially those in non-traditional disciplines, often must endure loneliness and lack of support from peers and teachers. Studies show that the presence of female instructors or staff who act as mentors and support female students can make a significant difference in the continuation of their education. In Uganda, for example, the presence of female role models meant that women were more likely to persevere with their education, and women in non-traditional sectors especially benefited from additional support (Buehren and van Salisbury, 2017; Campos et al., 2015).

A second, internal driver of gender inequality in TVET institutions concerns the facilities of TVET training centres themselves. Often TVET institutions lack basic features for women, such as separate washrooms or change rooms, safe spaces to study or relax, childcare facilities, or even transportation services for girls and young women in less accessible communities. Research on the provision of free sanitary pads for students, and safe washrooms in educational institutions, for instance, has been shown to significantly improve the attendance of female students in educational programs (Montgomery, Ryus, Dolan, Dopson and Scott, 2012).

The issue of accessibility of TVET classes is another oft-cited issue in the literature on gender and TVET. For those girls and young women in rural and less accessible areas, or for those with added childcare or domestic responsibilities there is a clear need for the development of flexibility in course delivery, whether it be in terms of the timing of classes, or the location of classes (UNESCO, 2020). If programs fail to consider these potential constraints, they may face lower take-up rates for women, leading to higher dropout and lower impacts (Chakravarty, Das, and Vaillant, 2017) and gender inequalities will persist, as TVET opportunities will remain out of reach for many young women and girls.

Interestingly, recent contributions to this discussion indicate that the covid-19 pandemic may present an opportunity to address issues of flexibility in TVET. As TVET institutions look to alternative forms of course delivery, such as online classes, virtual learning, and shorter, more module-based courses, there is the potential for this to benefit women and girls. The benefit will only be possible, however, gender-analysis informs the development of these new tools and formats for learning in TVET and issues of the gender digital divide are also addressed.

A third area of gender inequality in TVET identified in the literature concerns the issue of curricula. Curriculum content can be another mechanism for the reinforcement of gender inequality in TVET settings (Blumberg, 2008). Simmonds (2014), for instance argues this can happen when existing inequalities are not considered in curriculum design and then are transmitted through the curriculum in a way that strengthens stereotypes about gender and the inequality of opportunities. While there is a paucity of research on gender-bias in curriculum in the African TVET sector, the research that does exist suggests that gender equality is likely neglected at multiple stages of the curriculum development process (Blumberg, 2008; Hey, 2010; Simmonds, 2014; Relebohile, 2005; UNDP, 2004). Women are often under-represented in the initial consultation, as well as the design and writing stages of curriculum development (Hey, 2010; Simmonds, 2014). Curriculum content itself also tends to reinforce either women's invisibility or discriminatory gender stereotypes. Examples of gender-bias in 
curriculum include language use, that privileges and assumes a male-identity and a male-centred perspective, such as the use of male pronouns, and characters in illustrative case studies (Blumberg, 2008; Hey, 2010; Simmonds, 2014). Where case studies do include females, they tend not to portray men and women (and their work) as having equal value. Images of males were also more prevalent in TVET curriculum content than women, and images of women rarely used in curriculum of non-traditional subjects (Simmonds, 2014; Blumberg, 2008). There is also a lack of attention to gender equality and women's empowerment in the world of work. As Simmons $(2014,648)$ argues about educational curriculum in South Africa, "the assumption underlying this seems to be that gender equality and the empowerment of women are unattainable or that they are unimportant". Though literature on gender in the African TVET curriculum is scarce, it still demonstrates a need for the TVET curriculum to act as "an agent of change" as opposed to another aspect of TVET institutions that perpetuate and entrenched gender inequality. While there are exceptions, TVET curriculum on the continent continues to present stereotypical and binary perspectives rooted in patriarchal sociocultural tradition (Simmons, 2014). Beyond language, images and case studies privileging a male-perspective, there is also the question of gender-bias in assessments, and pedagogical approaches. Indeed, while female pass rates in TVET are slightly higher than male in specific courses and countries (Mozambique and Tanzania), in the majority of countries there are significant gender imbalances in pass rates in favour of male students (UNESCO, 2013). Instructor training and pedagogical approaches to teaching and learning in TVET still have much room for improvement in terms of their gender-responsivity (UNESCO, 2013).

A final and significant internal driver of gender inequality in TVET that is discussed in the literature concerns the area of apprenticeships and the transition to work. Apprenticeships, especially in sectors and industries where women are under-represented, tend to discriminate against females. In countries where traditional gender roles limit women's participation in public life, companies will often not even hire women where males dominate in a specific workforce. Thus, for girls and women engaged in sectors where females are under-represented (e.g., plumbing, welding, carpentry, construction, electricity, or other trades, etc.), apprenticeships are difficult to obtain and tend to reflect many of the gender barriers discussed above. Employers in these sectors fail to appreciate the skills and knowledge that female students have worked hard to gain. In cases where females can secure an apprenticeship, they often face discrimination, sexual harassment, a lack of support a lack of flexibility, and an environment where they may not have access to safe and appropriate facilities. Girls and young women often fail to secure apprenticeships in non-traditional sectors for these reasons. The paucity of institutions for contract negotiation and enforcement for student apprenticeships and internships are another compounding factor, as employers more commonly rely on wordof-mouth for hiring - which implicitly favours males in the labour market (Buehren and Van Salisbury, 2017; Chakravarty, Das and Vaillant, 2017). However, when girls and women are supported by mentors or through other types of supportive relationships with people in their chosen industries, they tend to do well in apprenticeships and in the sector more generally. In fact, in a study of women in TVET in Uganda and Ethiopia, Buehren and Van Salisbury (2017) the strongest predictor of a young woman's decision to enrol in male-dominated technical and vocational courses and achieve success is her existing relationships with people who work in the associated trade $(2017 ; 3)$. The literature points to the need for policies and practices that promote gender-awareness for both instructors, employers and industry partners so that preconceptions of the ability of women and girls in non-traditional fields can be overcome and female students can have better possibilities for successful internships. TVET instructors often lacked a strong connection to the current situation and demands of the labour market so 
closer links between TVET and the employment sector are necessary for Africa's TVET sector in general, but also to ensure female students are not put at a disadvantage. Ensuring genderawareness training for both instructors and employers and ensuring the development of, and access to networks of female peers and mentors in the sector are both recommendations highlighted in the literature that will help promote successful and safe internships for women and promote a smooth transition to work for female students in TVET. The network of mentors may be especially important after graduating as too frequently, even where girls and women are able to acquire skills for work, they often face social, cultural, economic, and practical constraints that pose barriers to their making full use of their skills in the world of work, and are more likely than men to be unemployed, even after training.

\section{Gender Equality in TVET: Summary of the policy Landscape in Africa}

The final section of this literature review takes a brief look at the policy landscape of gender in TVET, and the efforts to promote gender equality and gender mainstreaming practices within the sector. While the following is not exhaustive, it does provide a cursory view of the current state of gender in TVET policy and points to further directions for future policy making and standardization efforts. Two general observations can be made. First, the policy landscape surrounding TVET in Africa is disjointed in general, and there is no comprehensive policy governing gender in TVET specifically - whether at the continental, regional or country-level. Secondly policy documents use a range of terminology when addressing issues surrounding gender and equality in TVET. For example, "women", "females", and "gender" are often used interchangeably. Language is, of course, powerful, and inconsistencies in language and terminology can influence the scope of the policy, the stakeholders with whom to engage, which governmental ministries are responsible, as well as budget allocation for strategy and implementation.

Broadly speaking, gender is referenced in TVET policy in the three general ways. First, policy that refer to the external barriers particularly socio-cultural ones that contribute to perceptions of female roles and occupations and attracting more women to TVET; Second, policies that address the barriers within the TVET system such design of institutions, gender committees and internal standards of practice; and third, policies that support transition of women to the workplace in non-traditional occupations (Van den Bergh Collier, E., 2017).

The African Union's 'continental strategy for TVET to foster youth employment, for instance, highlights the gender divisions in choice of occupation and the stereotyping of women's representation in certain professions, which prevents women from equal access to male dominated sectors. This strategy highlights the role of government in reducing gender inequalities and discrimination and TVET. It asserts that nothing less than a paradigm shift is required to ensure equal representation of women and girls across all sectors, because what is needed is a change in mindset both within TVET institutions and in the workplace when it comes to gender and gender roles. The strategy also mentions that the notion that certain domestic jobs should be done by women and that these jobs do not require certification or training should be challenged (African Union, 2018).

Some, but not all, individual countries also have their own national TVET policies that make reference to gender. Sudan's TVET policy (2013), for example, states a commitment to the elimination of gender inequities. It notes that formal education and training are not as focused on gender barriers and so the TVET sectors must address regional imbalances to support equity and social inclusion. Kenya's draft TVET policy (2014) specifies the need for affirmative action to promote gender equity, states that one of its objectives includes improving access and equity according to gender and formulates one of its guiding principles as the promotion 
of gender non-discrimination. Kenya serves as a good example of linking policy to practice, with gender being given prominence throughout the TVET strategic plan 2018-2020. Rwanda's TVET policy (2015) is unique in that it mentions the internal and external barriers that have led to the under-representation of women and girls in the TVET system and notes that policy responses are required to address these challenges. Many countries, however, lack a focus on gender in TVET policy, if not lack a TVET policy overall. In many cases policies are more than a decade old, out of date with current realities, and/or still in a draft version. It is this lack of gender policy overall that poses the greatest hurdle to advancements in this area.

While mere policy making is not sufficient, and a gap in strategies for implementation is also present, the lack of a strong parent TVET strategy, makes developing gender specific TVET policy even harder. Furthermore, as observed in many countries in the region, there is a lack of coordination for TVET policy making, as frequently issues pertaining to the TVET sector fall under different or multiple ministries making it unclear which ministry has responsibility for TVET (Kandjii-Murangi 2016). A review of regional and country TVET policies, such as those mentioned above, reveal that there are no specific policies for gender equality in TVET, but rather international gender policies, such as CEDAW (UN 1979), or a country's national gender policies, are used as a reference point when addressing gender discrimination in TVET. At the specific TVET policy/strategy level there are mentions of gender, but always in the broader context of economic and social discrimination, and equal access to economic opportunity. The attention given to gender is approximately equal to that given to issues of disability, rurality, and other marginalized groups. An understanding of the intersectionality of identities, and accordant policies that might address, for example, women and girls who suffer from poverty and are living with a disability, is never considered. This deficiency in policy highlights a lack of understanding and theorization on the multiple forms of discrimination that may face African students in TVET. International frameworks for standards of practice in TVET exist (i.e., UNESCO, ILO), but there is a lack of African-focused frameworks for gender equality policy in TVET. Additionally, as noted above, the research on gender equality is disjointed, incomplete and suffers from a lack of comprehensiveness. More needs to be done in this regard to harness the power of gender-data and develop a more comprehensive and robust gender equality policy for the TVET sector. This would no doubt help improve gender-responsive interventions and practices.

\section{Conclusion}

Gender analysis of Africa's TVET sector is making progress, but there is much more that needs to be done. The literature on gender and TVET tends to be disjointed and uneven and lacks connection to related broader academic work on equality, gender and development in Africa. While studies exist on a range of gender inequality challenges in TVET, the issues are under researched and under theorized. Most notably, the connections between gender inequality in TVET and sustainable development on the continent are not well advanced in the TVET literature. This is problematic as it limits the understanding of how gender-responsive TVET reforms may contribute to Africa's economic development, the promotion of the SDGs and Agenda 2063. What can be observed from this review of literature is that systems of gender inequality in society give rise to the inequalities that exist between men and women in the TVET sector. Gender inequalities within TVET institutions in turn reinforce gender inequalities in labour markets. Thus, rather than act as an engine for the promotion of gender equality and women's economic empowerment, Africa's TVET sector may be acting as a site of reproduction of gender inequalities in the labour market, the economy and society in general. Policy in this area 
is not complete nor sufficiently comprehensive to address this challenge, and strategies for action and intervention are also too, despite recent progress.

Having said this, the progress that has been made, highlights the potential that genderresponsive TVET reforms have on the ability of the TVET sector to contribute to economic development on the continent. Ensuring women's equal and full participation in the labour force, and particularly in non-traditional sectors, like STEM, are vital for not just women's economic empowerment, but for the overall promotion of sustainable development in Africa. A major challenge for Africa's TVET sector is thus to overcome the obstacles that keep women and girls from acquiring the skills and knowledge they need to take up higher-paying, higher productivity jobs, and thereby promoting economic development and sustainable development for all. This challenge must be met through more research and better theorization of gender inequality in the TVET sector to inform robust policy development in this area and guide strategic recommendations for implementation and action. Gender equality and women's empowerment is a fundamental development goal and part of Africa's sustainable economic vision. Enhancing the ability of the TVET sector to promote better outcomes for women and girls is thus advancing the wellbeing of all.

\section{Literature}

Adelakun, O and Oviawe, J (2015) Strategies for Enhancing Females Participation in Technical, Vocational Education and Training (TVET) in Nigeria. Advances in Social Sciences Research Journal 2(4)

Agarwal, B. (2018). Gender equality, food security and the sustainable development goals. Current Opinion in Environmental Sustainability. 34. Pp 26-32.

Agbara, W., Chagbe, M. B., \& Achi, T. T. (2018). Challenges of women in technical and vocational education: A case study of federal college of education (technical), Gusau. International Journal of Vocational and Technical Education, 10(1), pp7-13.

Akinsanya, O. O., and Onah, F.O. (2012). The Role of Women in Academics: Issues, Challenges And Perspectives. Journal of Research in National Development, 10 (2) (Online). Available from https://www.ajol.info/index.php/jorind/index (Accessed 10 December 2020).

Amoamah, M.O., Brew, E.M., Ampiaw,R.E. and Dadzie, J. (2016). Gender Inequality in TVET Institutions - Bridging the Gap: The Case of Accra Polytechnic in Mathematical Theory and Modeling. 6,(1)

Andersson, N., Paredes-Solis, S., Milne, D., Omer, K., Marokoane, N., Laetsang, D., Cockcroft, A. (2012). Prevalence and risk factors for forced or coerced sex among school-going youth: national cross-sectional studies in 10 southern African countries in 2003 and 2007. BMJ Open. 2(2) (Online), Available from https://bmjopen.bmj.com/content/2/2/e000754. (Access 10 December 2020).

Arias, O., Evans, D.K. and Santos, I. (2019). The Skills Balancing Act in Sub-Saharan Africa Investing in Skills for Productivity, Inclusivity, and Adaptability. Agence française de développement and the World Bank.

Arnold, D., Gelaye, B., Goshu, M., Berhane, Y., Williams, M.A. (2008). Prevalence and risk factors of gender-based violence among female college students in Awassa, Ethiopia. Violence Vict. 23(6). Pp 787-800

Asukwo, A., \& Moses, D., Ibanga, I., and Adamu Yusuf, M. (2019). Achieving Sustainable Development Goals 2016-2030 in Nigeria through Technical and Vocational Education and Training (TVET). 
Achieving Sustainable Development Goals 2016-2030 Through Global Partnership in TVETAt: International Vocational Education and Training Association (IVETA), Abuja, Nigeria. November, 2019

Ayalew Ali, D., Deininger, K., Goldstein, M. (2014). Environmental and gender impacts of land tenure regularization in Africa: Pilot evidence from Rwanda, Journal of Development Economics, 110, pp. 262-275 (Online). Available from: https://doi.org/10.1016/j.jdeveco.2013.12.009. (Accessed 10 December 2020)

Beyene, A., Chojenta, C., Roba, H.S., Melka, A.S. and Loxton, D. (2019). Gender-based violence among female youths in educational institutions of Sub-Saharan Africa: a systematic review and meta-analysis. Systematic Reviews. 8(59). (Online) Available from https://systematicreviewsjournal.biomedcentral.com/articles/10.1186/s13643-019-0969-9. (Accessed 13 December 2020).

Blumberg, R.L. (2008) The invisible obstacle to educational equality: gender bias in textbooks. Prospects 38, pp 345-361. (Online) Available from: https://doi.org/10.1007/s11125-0099086-1. (Accessed 13 December 2020)

Bonzet, R. and Frick, B.L. (2019). Gender transformation experiences among women leaders in the Western Cape TVET Sector: A narrative response. Education as Change, 23(1) pp1-21. (Online) Available from: https://dx.doi.org/10.25159/1947-9417/3521 (Accessed on 13 December 2020)

Buehren, N., and van Salisbury, T. (2017). Female Enrollment in Male-Dominated Vocational Training Courses: Preferences and Prospects. Gender Innovation Lab Policy Brief, World Bank, Washington, DC.

Bunyi, G. (2003). Interventions That Increase Enrolment Of Women In African Tertiary Institutions. A case study prepared for a Regional Training Conference on Improving Tertiary Education in Sub-Saharan Africa: Things That Work! (Online) Available from: https://citeseerx.ist.psu.edu/viewdoc/download?doi=10.1.1.553.6062\&rep=rep1\&type=pdf . (Accessed 13 December 2020).

Campos, F., Goldstein, M., McGorman, Boudet, A.M., and Pimhidzai, O. (2015). Breaking the Metal Ceiling: Female Entrepreneurs Who Succeed in Male-Dominated Sectors. Policy Research Working Paper 7503, World Bank, Washington, DC

Carlana, M. (2019) Implicit Stereotypes: Evidence from Teachers' Gender Bias, The Quarterly Journal of Economics, 134 (3) pp 1163-1224

Chakravarty, S.,Das, S. and Vaillant, J. (2017) Gender and Youth Employment in Sub-Saharan Africa: A Review of Constraints and Effective Interventions. World Bank Policy Research Working Paper. 8245

Cheruiyot, S and Munyi, F.W. (2019) Gender Inclusion in TVET: An Examination of Sustainable Interventions In Selected TVET Institutions In Kenya- Sustainable development in education. Academic Insights. 4(2).

Cornel, J and Leyaro, V. (2019). Gender Differential Effects of Technical and Vocational Training: Empirical Evidence for Tanzania. CREDIT. Discussion Papers 2019-04. University of Nottingham

Dietrich, C., Huang, A., Thomas, A., Toujas-Bernaté, J. (2016). Women's Opportunities and Challenges in Sub-Saharan African Job Markets. IMF Working Paper WP/16/118.

Douwe, G. and Papier, J. (2015). TVET teacher education in Africa Synthesis report. European Commission

Ellsberg, M and Heise, L (2005). Researching violence against women: practical guidelines for researchers and activists. World Health Organization.

Foster, H. (2012) Women and TVET: Report of the UNESCO-UNEVOC online conference.

166

Gender and TVET in Africa

Futures of Education, Culture \& Nature - Learning to Become 
Fulu, E. (2016). Violence against women and girls. GSDRC Professional Development. 32. University of Birmingham

Gaidzanwa, R. (2008) Beyond Primary Education: Challenges and Approaches to Expanding Learning Opportunities in Africa. Semantic Scholar

Gaidzanwa, R. (2007). Forthcoming. Academic Women at the University of Zimbabwe: Institutional and Individual Issues in Reforming Higher Education in a Stressed Economy. In: AssiéLumumba, N .T. (ed.), Women and Higher Education in Africa Reconceptualizing GenderBased Human Capabilities and Upgrading Human Rights to Knowledge. Abidjan, CEPARRED.

Government of (2013) Sudan TVET Policy. Khartoum. (Online) Available from: https://www.ilo.org/wcmsp5/groups/public/---africa/---ro-abidjan/---sro-cairo/documents/publication/wcms_243649.pdf (Accessed 10 December 2020).

Hey, B. (2010). Guidelines on Gender Fair Curriculum Development. WUS Austria.

Hoftijzer, M., Levin, V., Santos, I. and Weber, M. (2020). TVET Systems' response to COVID-19: Challenges and Opportunities. World Bank Group.

IDRC. (2019). Policy-relevant lessons to help African youth develop workplace skills. Research in Action Series. (Online) Available from: https://www.idrc.ca/en/research-in-action/policy-relevant-lessons-help-african-youth-develop-workplace-skills (Accessed on 10 December 2020).

Iliyasu, Z., Abubakar, I. S., Aliyu, M.H., Galadanci, H.S., Salihu, H.M. (2011). Prevalence and correlates of gender-based violence among female university students in Northern Nigeria. Afr J Reprod Health. 15(3) pp. 111-9.

ILO (2020). The gender divide in skills development: Progress, challenges and policy options for empowering women. ILO Policy Brief. (Online) Available from: https://www.ilo.org/wcmsp5/groups/public/---ed_emp/---ifp_skills/documents/publication/wcms_244380.pdf. (Accessed on 5 December 2020)

Johanson, R. and Okema, J. (2011) Business, Technical Vocational Education, and Training SubSector Analysis Technical Paper 5: BTVET Delivery, prepared for the Ministry of Education and Sports, Belgian Technical Cooperation/BTC and the World Bank, Kampala, Uganda.

Kennedy, A.C. (2005). Resilience among urban adolescent mothers living with violence: listening to their stories. Violence Against Women. 11(12) pp. 1490-514.

Kennedy, A.C. and Bennett, L. (2006). Urban adolescent mothers exposed to community, family, and partner violence: is cumulative violence exposure a barrier to school performance and participation? J Interpers Violence;21(6) pp 750-73.

Krug, E.G., Mercy, J.A., Dahlberg, L.L., Zwi, A.B. (2002) The world report on violence and health. Lancet. 360 (9339). Pp 1083-8.

Kandjii-Murangi, I. (2016). TVET, higher education and innovation policy review: Namibia. UNESCO. (Online) Available from: https://unesdoc.unesco.org/ark:/48223/pf0000245818 (Accessed 13 December 2020)

Letta, T., Feleke, A. and Derseh, L.(2014). Assessment of violence and associated factors among rural high school female students, in Hadiya zone, southern nation and nationalities peoples' region, Ethiopia. Open Access Library Journal. 1(03):1.

Leyaro, V. and Joseph, C. (2019) Employment Mobility and Returns to Technical and Vocational Training: Empirical Evidence for Tanzania. University of Nottingham, CREDIT. Discussion Papers 2019-03,

Lifanda, K.N. (2005) Education and training of women and the girl-child. Online discussion for the review of beijing+10 (UNESCO/UNICEF). UNESCO (moderator). JANUARY 10- FEBRUARY 4, 2005

Lloyd, C.B. and Mensch, B.S. (2008) Marriage and childbirth as factors in dropping out from school: An analysis of DHS data from sub-Saharan Africa, Population Studies, 62:1, 1-13 
Manyike, P.C., Chinawa, J.M., Aniwada, E., Udechukwu, N.P., Odutola, O.I. and Chinawa, T.A. (2015). Child sexual abuse among adolescents in southeast Nigeria: a concealed public health behavioral issue. Pak J Med Sci. 31(4) pp. 827-32.

Markos, J., Semahegn, A. and Berhanu, B. (2014) Assessment of sexual violence and associated factors among high school students in Harari Regional State, Harar Town. East Ethiop Sci Res. 2(5) pp. 91-7.

Mbelle, N, Mabaso, M, Setswe, G, \& Sifunda, S. (2018). Predictors of unplanned pregnancies among female students at South African Technical and Vocational Education and Training colleges: Findings from the 2014 Higher Education and Training HIV and AIDS survey. SAMJ: South African Medical Journal, 108 (6), pp 511-516 (Online). https://dx.doi.org/10.7196/samj.2018.v108i6.12744. (Accessed 10 December 2020)

McGrath, S. (2011). Where to Now for Vocational Education and Training in Africa? International Journal of Training Research. 9 (1-2) pp. 35-48. doi:10.5172/ijtr.9.1-2.35.

McGrath, S. (2012).Vocational Education and Training for Development. International Journal of Educational Development. 32 (5) pp. 623-631.

McGrath, S., and Powell, L. (2015). Vocational Education and Training for Human Development. In S. McGrath and Q. Gu (edts) Routledge Handbook of International Education and Development, 276-288. Abingdon: Routledge.

McGrath, S., Ramsarup, P., Zeelen, J. , Wedekind, V, Allais, S., Lotz-Sisitka, H., Monk, D. , Openjuru, G. and Russon, J. (2020) Vocational education and training for African development: a literature review, Journal of Vocational Education \& Training, 72(4) pp 465-487

Meena, R. (2007). Women's Participation in Higher Levels of Learning in Africa. In: AssiéLumumba, N. T. (ed.), Women and Higher Education in Africa Reconceptualizing Gender-Based Human Capabilities and Upgrading Human Rights to Knowledge. Abidjan, CEPARRED.

Ministry of Education, Science and Technology. (2014) Kenya draft technical and vocational education and training (TVET) policy. 2014. Available at http://www.knqa.go.ke/wp-content/uploads/2018/10/first_final_draft_tivet_policy.pdf (Accessed on 10 December 2020).

Ministry of Education. TVET policy. (2015). Republic of Rwanda. Available at https://www.rp.ac.rw/fileadmin/user_upload/TVET_POLICY.pdf (Accessed on 13 December 2020).

Mirsky, J (2003) Beyond victims and villains: addressing sexual violence in the education sector. Panos Institute. (Online) Available from: http://www.cwhn.ca/en/node/23031. (Accessed 12 December 2020)

Mlama, O.M. (1998). Increasing Access and Equity in Higher Education: Gender Issues, In: Shabani J. (eds.) Achievements, Challenges and Prospects, Dakar, Regional Office for Higher Education in Africa, (BREDA)

Montgomery, P., Ryus, C.R., Dolan, C.S., Dopson, S., Scott, L.M. (2012). Sanitary Pad Interventions for Girls' Education in Ghana: A Pilot Study. Plos One. 7(10). (Online) Available from: https://doi.org/10.1371/journal.pone.0048274. (Accessed 10 December 2020).

Moletsane, R (2005). Looking Back, Looking Forward: Analysing Gender Equality in South African Education 10 Years after Beijing. Agenda: Empowering Women for Gender Equity, (64) pp 8088.

Mullu, G., Gizachew, A., Amare, D., Alebel, A., Wagnew, F., Tiruneh, C., Worku, M., Kediri, R., Tamiru, S. and Demsie, T.(2015). Prevalence of gender based violence and associated factors among female students of Menkorer high school in Debre Markos town, Northwest Ethiopia. Science. 3(1) pp. 67-74.

Mutarubukwa, P., and Mazana, M. (2018). Stigmatization among female students in natural science related courses: a case of technical and vocational education training institutions in 
Tanzania. Business Education Journal. 1(4). (Online). Available from file:///C:/Users/n01328701/Documents/PERSONAL/Research/policy/STIGMATIZATIONAMONGFEMALESTUDENTS.pdf (Accessed 10 December 2020)

Ngugi, M. and Muthima, P. (2017). Female Participation in Technical, Vocational Education and Training Institutions (TVET) Subsector: The Kenyan Experience. Public Policy and Administration Research. 7(4) (Online) Available from: https://iiste.org/Journals/index.php/PPAR/article/view/36735/37749 (Accessed on 13 December 2020)

Nimani, W. and Hamdela, B. (2015) Sexual violence and associated factors among high school students in Butajira town, South Ethiopia. Gen Med.

Nordman, C and Pasquier-Doumer, L (2012) Vocational Education, On-the-Job Training and Labour Market Integration of Young Workers in Urban West Africa. Working Paper. DIAL (Développement, Institutions et Mondialisation).(Online) Available from https://econpapers.repec.org/paper/diawpaper/dt201213.htm (Accessed 10 December 2020)

Nurhaeni, I. D. A. and Kurniawan, Y. (2018). Gender-Mainstreaming in Technical and Vocational Education and Training. IOP Conference Series: Materials Science and Engineering. 306.

Oando, S. and Ogola. W. (2015) Implications of sexual violence on the inequalities in TVET achievements. AfroTVET Journal, Eldoret Kenya. (Online). Available from: https://www.academia.edu/14606673/Implications_of_sexual_violence_on_the_inequalities_in_TVET_achievements (Accessed 10 December 2020).

Odondi, W., Maina L. and Muhia, N. (2020). The Risk to Achieving Sustainable Development Competencies: A Gendered Analysis of Access and Training Outcomes in TVET Institutions in Kenya. Africa Journal of Technical \& Vocational Education \& Training, 5 (1), pp. 18-28 (Online) Available from: https://www.afritvet.org/index.php/Afritvet/article/view/100. (Accessed 10 December 2020).

Office on the Status of Women. Dr Ellen Kornegay (contact) National Gender Policy Framework. (Online) Available from: https://www.ilo.org/dyn/natlex/natlex4.detail?p_isn=94056\&p_lang=en (Accessed 10 December 2020)

Ohene, S.A., Johnson, K., Atunah-Jay, S., Owusu, A. and Borowsky, I.W. (2019) Sexual and physical violence victimization among senior high school students in Ghana: risk and protective factors. Soc Sci Med. 46. Pp 266-75.

Oluniyi, A., Itohan, O. J. and Garba, B. (2015). Strategies for Enhancing Females Participation in Technical, Vocational Education and Training (TVET) in Nigeria, Advances in Social Sciences Research Journal, 2(4)

Omukhulu, D., Ogbanicael, L., \& Kimamo, G. (2016). Gender Mainstreaming in TVET Institutions in Kenya. Africa Journal of Technical and Vocational Education and Training, 1(1), pp 21-30 (Online). Available from: https://afritvet.org/index.php/Afritvet/article/view/9. (Accessed 13 December 2020)

Pelagia, M. and Mazana, M. (2017). Stigmatization among female students in natural science related courses: a case of technical and vocational education training institutions in Tanzania. Business Education Journal (BEJ). (Online) Available from: http://dspace.cbe.ac.tz:8080/xmlui/handle/123456789/169. (Accessed 13 December 2020)

Prendergast, $Y$ (2020) Developing skills programming through a gender lens- summary TVET inclusion. British Council.

Romero, T. and Folz, N (2015) Building Pathways for Working Children's Access to Education in Kenya Children Lead The Way Program. Save the children Canada

https://resourcecentre.savethechildren.net/node/14247/pdf/kenya-report-low-res-1.pdf

Rubagiza, J (2010) Gender analysis of the technical and vocational education and training (TVET) policy in Rwanda. Forum for African Educationalists Rwanda 
Sathos, I., and Rubiano-Matulevich, E. (2019) Minding the gender gap in training in Sub-Saharan Africa: Five things to know. World Bank Blogs. https://blogs.worldbank.org/africacan/mindinggender-gap-training-sub-saharan-africa-five-things-know (Accessed on 10 December 2020).

Simmonds, S. (2014). Curriculum-making in South Africa: promoting gender equality and empowering women (?), Gender and Education, 26(6) pp. 636-652.

Powell, L., and McGrath, S. (2018). The Long and Winding Road to the Labour Market. Trends in Vocational Education and Training Research., Nägele, C and Stalder, B(edts). Journal of vocational education \& training 485

Powell, L., and McGrath, S. (2019). Capability or Employability: Orienting VET toward 'real Work'." In S. McGrath, M. Mulder, J. Papier, and R. Suart (edts) Handbook of Vocational Education and Training. Basel: Springer

Shimekaw, B., Megabiaw and B., Alamrew, Z. (2013) Prevalence and associated factors of sexual violence among private college female students in Bahir Dar city, North Western Ethiopia. ResearchGate Health 05(06) pp. 1069-1075.

Taiwo, M.O. (2014). Best Practices in Gender Mainstreaming in Academia: Lessons from African Higher Education Institutions in International Journal of Humanities Social Sciences and Education (IJHSSE) Volume 1 (10) pp 81-87. Available from: https://www.arcjournals.org/pdfs/ijhsse/v1-i10/12.pdf. (Accessed 10 December 2020).

Tchouassi, G. (2012). Does Gender Equality work for Sustainable Development in Central Africa Countries? Some Empirical Lessons. European Journal of Sustainable Development, 1(3), pp 383-398 https://www.researchgate.net/publication/267507209 Does Gender_Equality_work_for_Sustainable_Development_in_Central_Africa_Countries_Some_Empirical_Lessons (Accessed 10 December 2020).

Technical and vocational education and training authority. Strategic Plan 2018-2022. Kenya. http://tveta.go.ke/wp-content/uploads/2019/06/TIVETA-STRATEGIC-PLAN-2-e-pub_2-Compressed.pdf (Accessed on 10 December 2020).

Umana, J.E., Fawole, O.I. and Adeoye, I.A. (2014). Prevalence and correlates of intimate partner violence towards female students of the University of Ibadan, Nigeria. BMC Womens Health. $14(131)$

UNESCO (2011). Women and TVET. Report of the UNESCO-UNEVOC online conference. Helga Foster (moderator). December 5-15, 2011.

UNESCO (2013) Status of TVET in the SADC Region. Assessment and Review of Technical and Vocational Education and Training (TVET) in the Southern African Development Community Region and of the Development of a Regional Strategy for the Revitalisation of TVET . France

UNESCO (2020). Global Education Monitoring Report - Gender Report: A new generation: 25 years of efforts for gender equality in education. Paris, UNESCO

UN General Assembly, Convention on the Elimination of All Forms of Discrimination Against Women, 18 December 1979, United Nations, Treaty Series, vol. 1249, p. 13: https://www.refworld.org/docid/3ae6b3970.html [accessed 14 December 2020]

Van den Bergh Collier, E. (2017). Skills Development as a Means to Women's Empowerment:

Integrating Gender Equality in TVET. Colleges and Institutes Canada.

Vila, B. (2015) THEMATIC BRIEF: GENDER, EDUCATION AND TRAINING. European Union. https://europa.eu/capacity4dev/public-gender/documents/thematic-brief-gender-education-and-training (Accessed 10 December 2020).

Wandera, S.O., Clarke, K., Knight, L., Allen, E., Walakira, E., Namy, S., Naker, D. and Devries, K. (2017) Violence against children perpetrated by peers: a cross-sectional school-based survey in Uganda. Child Abuse Negl. 2017;68:65-73. 
Woldemichael, A. (2019). The "Missing Women" in African Labor Markets in Monga, C., Shimeles, A., Woldemichael, A. (eds) Creating Decent Jobs: Strategies, Policies and Instruments. Abidjan: African Development Bank

Woldemichael, A. (2020). Closing the gender gap in African labor markets is good economics Foresight Africa: Top priorities for the continent 2020-2030. Brookings. Africa Growth Initiative. Brookings Institution. https://www.brookings.edu/wpcontent/uploads/2020/01/ForesightAfrica2020_20200110.pdf (Accessed 13 December 2020)

WORLD BANK GROUP (2016).Gender Equality, Poverty Reduction, and Inclusive Growth Gender Strategy 2016-2023. 